\title{
KEPITING AIR TAWAR (DECAPODA: BRACHYURA) DARI LERENG SELATAN GUNUNG SLAMET, KABUPATEN BANYUMAS, PROVINSI JAWA TENGAH
}

\section{FRESHWATER CRAB (DECAPODA: BRACHYURA) FROM SOUTHERN SLOPE OF MT. SLAMET, BANYUMAS REGENCY, CENTRAL JAVA PROVINCE}

\author{
Rena Tri Hernawati \\ Museum Zoologicum Bogoriense (MZB), Research Center for Biology, Indonesian Institute of \\ Sciences-LIPI; Jl. Raya Jakarta Bogor km 46, Cibinong, West Java 16911, Indonesia \\ E-mail: rena.trihernawati@gmail.com
}

(diterima April 2019, direvisi Oktober 2019, disetujui Desember 2019)

\begin{abstract}
ABSTRAK
Kepiting air tawar menyukai perairan yang bersih dengan ketinggian tertentu. Hulu sungai Banjaran yang terletak di Gunung Slamet mempunyai kondisi fisik dan kimiawi yang baik sebagai habitat kepiting air tawar. Penelitian untuk mengetahui pemilihan ketinggian sebagai tempat hidup kepiting yang dilakukan di lereng bagian selatan Gunung Slamet, dengan metoda random purpose sampling, menemukan lima jenis kepiting yaitu Geosesarma sp. hidup pada ketinggian $787 \mathrm{~m}$ dpl., Malayopotamon lipkei ditemukan pada 286-800 m dpl., Parathelphusa bogorensis pada $105-195$ m dpl., Parathelphusa convexa pada $105 \mathrm{~m}$ dpl., dan Terrathelphusa sp. pada 916-997m dpl. Diberikan juga kunci identifikasi untuk jenis yang ditemukan di Sungai Banjaran.
\end{abstract}

Kata kunci: Gecarcinucidae, Kepiting air tawar, ketinggian, Sesarmidae, Potamidae.

\begin{abstract}
Freshwater crabs inhabit clean waters at a certain altitude. The upstream of Banjaran river which is located on the Mount Slamet has good physical and chemical conditions suitable for freshwater crabs. Research to determine a habitat of fresh water crabs according to altitude was carried out on the southern slopes of the Mount Slamet has find five species namely Geosesarma sp. at altitude $787 \mathrm{~m}$ asl., Malayopotamon lipkei at 286-800 m asl., Parathelphusa bogorensis at 105-195 $\mathrm{m}$ asl., P. convexa at $105 \mathrm{~m}$ asl., and Terrathelphusa $\mathrm{sp}$. at $916-997 \mathrm{~m}$ asl. A key to the species found in Sungai Banjaran is provided.
\end{abstract}

Keywords: Elevation, freshwater crab, Gecarcinucidae, Sesarmidae, Potamidae.

\section{PENDAHULUAN}

Pulau Jawa memiliki tiga suku kepiting air tawar yaitu Suku Gecarcinucidae, Potamidae, dan Sesarmidae (Bott 1970; Ng 1989; Wowor \& Tan 2010; Ng et al. 2015; Ng \& Wowor 2019). Pada penelitian sebelumnya di lereng selatan Gunung Slamet, Banyumas, ditemukan tiga jenis kepiting air tawar yang termasuk kedalam dua marga, yaitu: Malayopotamon lipkei dari Suku Potamidae, Terrathelphusa chilensis dan Terrathelphusa kuhli dari Suku Gecarcinucidae (Ng 1989; Wowor \& Tan 2010). Jenis kepiting air tawar menempati habitat yang berbeda berdasarkan ketinggian (Ng et al. 2010), dan mempunyai peran penting di ekosistem akuatik, salah satunya sebagai organisme pengurai (Grinang \& Ng 2015; Ng 1989; Whitten et al. 2013).

Sungai merupakan tempat hidup makrobenthos seperti moluska, serangga air, udang, dan kepiting (Deekae \& Abowei 2010). Selain itu sungai juga memiliki fungsi hidrologis yang sangat penting diantaranya sebagai tempat transmisi air, penyangga air pada saat hujan, dan pelepasan air secara perlahan (van Noordwijk dkk. 2004). Kepiting sangat menyukai kondisi air yang jernih bahkan bisa digunakan sebagai indikator kebersihan suatu sungai atau perairan (Cumberlidge 1999). Penelitian ini dilakukan 
di Sungai Banjaran yang beraliran cukup deras, berhulu di kawasan hutan lindung di Gunung Slamet dan kondisinya relative terjaga karena keberadaan Kebun Raya Baturraden. Adapun penelitian ini bertujuan untuk menginventarisasi kepiting yang ada di lereng selatan Gunung Slamet berdasarkan ketinggian yang berbeda.

\section{METODE PENELITIAN}

Pengambilan sampel dilakukan pada tanggal 7-9 Februari 2014 di Sungai Banjaran, Purwokerto-Banyumas. Metode penelitian yang digunakan, yaitu Purposive Random Sampling, karena kepiting sungai merupakan organisme yang hidup soliter atau tidak mengelompok (Cumberlidge 1999; Thiel \& Baeza 2001). Penentuan anak sungai yang ditelusuri diatas Sungai Banjaran ditentukan berdasarkan Peta Rupabumi Indonesia edisi: 1-2000 dengan skala 1: 25.000 dari Badan Informasi Geospasial (BIG). Koleksi kepiting dilakukan pada 16 lokasi dengan berbagai posisi ketinggian, yaitu: stasiun 1 dengan ketinggian 105 dpl., Stasiun 2: $195 \mathrm{dpl}$, stasiun 3: 286 dpl. stasiun 4: 542, stasiun 5: 560, stasiun 6: 575, stasiun 7: 637, stasiun 8: 787, stasiun 9: 800, stasiun 10: 916, stasiun 11: 940, stasiun 12: 997, stasiun 13: 1000, stasiun 14: 1030, stasiun 15: 1083, dan stasiun 16: $1106 \mathrm{~m} \mathrm{dpl,} \mathrm{sedangkan} \mathrm{titik}$ koordinat diperoleh menggunakan Global Positioning System (GPS) yaitu antara $7^{\circ}$ $24 ' 24.84 " \mathrm{~S} \quad 109^{\circ} 13^{\prime} 42.48^{\prime \prime} \mathrm{E}$ dan $7^{\circ} 17^{\prime} 59.51 " \mathrm{~S}$ $109^{\circ} 11^{\prime} 50.06^{\prime \prime E}$. Lokasi 12 bertumpuk dengan Lokasi 13 karena jaraknya yang sangat dekat dengan selisih ketinggian hanya sekitar $3 \mathrm{~m}$. Peta lokasi penelitian diambil dari Peta Ketinggian Indonesia yang bersumber dari DIVA-GIS (Gambar 1).

Pengambilan sampel menggunakan tangan kosong (hand picking) dan alat pancing beserta umpan berupa cacing/bekicot. Sampel yang diperoleh, dimasukkan kedalam alkohol $40 \%$ untuk fiksasi dan diganti dengan alkohol 96\% untuk preservasi. Data lokasi pengambilan

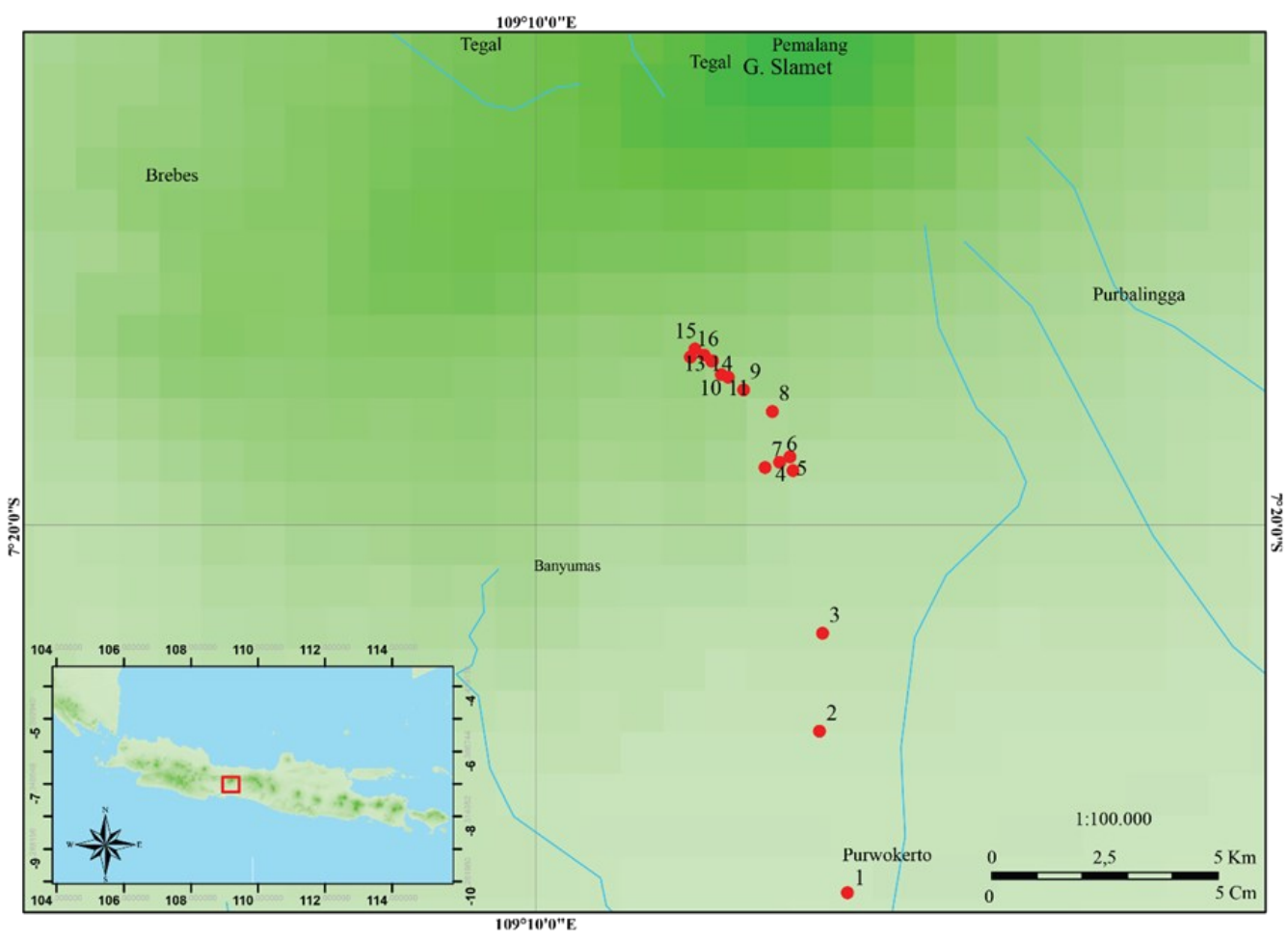

Gambar 1. Peta lokasi pengambilan sampel. 
sampel ketinggian, dan data ekologi yaitu titik koordinat, lebar sungai, dalam sungai, substrat pasir, lumpur, ukuran batuan $(<10 \mathrm{~cm}, 10-50$ $\mathrm{cm}$, dan $>50 \mathrm{~cm})$, dan kanopi.

Sampel diidentifikasi di Laboratorium Krustasea, Pusat Penelitian Biologi - LIPI, Cibinong dan disimpan di Museum Zoologicum Bogoriense (MZB). Pustaka yang digunakan untuk identifikasi mengacu pada Bott (1970), $\mathrm{Ng}$ (1989, 2004), Wowor \& Tan (2010), dan Ng \& Wowor (2019). Pengukuran (dalam mm) yang dilakukan menggunakan Vernier caliper dengan tingkat ketelitian $0.05 \mathrm{~mm}$ adalah panjang karapaks yaitu jarak panjang dari sisi posterior karapaks dan puncak rostrum, dan lebar karapaks yaitu jarak terbesar pada lebar karapaks (panjang karapaks $\times$ lebar karapaks).

\section{HASIL DAN PEMBAHASAN}

Dari 16 lokasi pengambilan sampel, pada lokasi 11, 13, 14, 15 dan 16 tidak didapatkan kepiting. Hal ini kemungkinan karena lokasi telah cukup tinggi sehingga kepiting semakin jarang. Walaupun demikian pada stasiun 12 dengan ketinggian 997 dpl masih didapat 1 kepiting jantan dari jenis Terrathelphusa sp. di Gunung Slamet. Catatan sebelumnya juga melaporkan Terrathelphusa dari Baturraden ketinggian $1000 \mathrm{~m}$ asl ( $\mathrm{Ng}$ 1989). Namun, kemungkinan jenis Terrathelphusa sp. dapat ditemukan lebih tinggi dari yang tercatat dipenelitian ini atau sebelumnya karena jenis lain Terrathelphusa kuhli ditemukan di Gunung Gede, Cibodas ditemukan pada ketinggian 1400 m dpl (Ng 1989). Selain itu, upaya pengambilan sampel juga terhalang medan yang sangat berbahaya berupa tebing dan jurang yang curam sehingga tidak memungkinkan untuk penelurusuran anak sungai.

\section{TAKSONOMI}

Bangsa Decapoda Latreille, 1802

Subbangsa Pleocyemata Burkenroad, 1963

Infrabangsa Brachyura Latreille, 1802

\section{Suku Sesarmidae Dana, 1851}

\section{Geosesarma sp.}

Gambar 2. A, D

Material. 3 jantan $(7,10 \times 8,25-9,75 \times 11,1$ $\mathrm{mm}), 3$ betina $(6,85 \times 7,90-7,80 \times 8,70 \mathrm{~mm})$, 12 anakan $(5,40 \times 6,25-3,40 \times 3,75 \mathrm{~mm})$ (MZB Cru 5195), anak sungai Banjaran di daerah Selada air, lokasi 8, Kalipagu, Desa Ketenger, Kecamatan Baturraden, Kabupaten Banyumas, Provinsi Jawa Tengah, 9 Februari 2014, kolektor R.T. Hernawati, I.Y. Prasetyo \& Karso

Material pembanding. Geosesarma dennerle holotipe: jantan $(14.4 \times 14.0 \mathrm{~mm})$ (MZB Cru 4061) dari Cilacap. Geosesarma hagen holotipe: jantan $(13.9 \times 13.3 \mathrm{~mm})$ (MZB Cru 4062) dari Cilacap. Geosesarma noduliferum 19 jantan $(6,55 \times 6,15-11,15 \times 12,50 \mathrm{~mm})$, 30 betina $(6,05 \times 6,70-11,15 \times 12,80 \mathrm{~mm})$ (MZB Cru 5229) dari Bogor. Geosesarma dennerle spesimen voucher: 2 jantan $(9,55 \times$ $10,65-9,95 \times 11,45 \mathrm{~mm}), 1$ betina $(10,40 \times$ $11,80 \mathrm{~mm}$ ) (MZB Cru 5236) dari toko kepiting hias di Jakarta Utara. Geosesarma hagen spesimen voucher: 1 jantan $(9,75 \times$ $11,90 \mathrm{~mm}), 1$ betina ukuran $(10,5 \times 11,95$ $\mathrm{mm}$ ) (MZB Cru 5235) dari toko kepiting hias di Jakarta Utara.

Diagnosis. Karapaks berbentuk persegi dengan permukaan memiliki banyak tonjolan, sedangkan kerutan berada di daerah metabranchial dan mesobranchial. Gigi epibrachial hanya satu. Bagian subterminal merus kaki jalan tidak memiliki duri, melainkan memiliki setae 


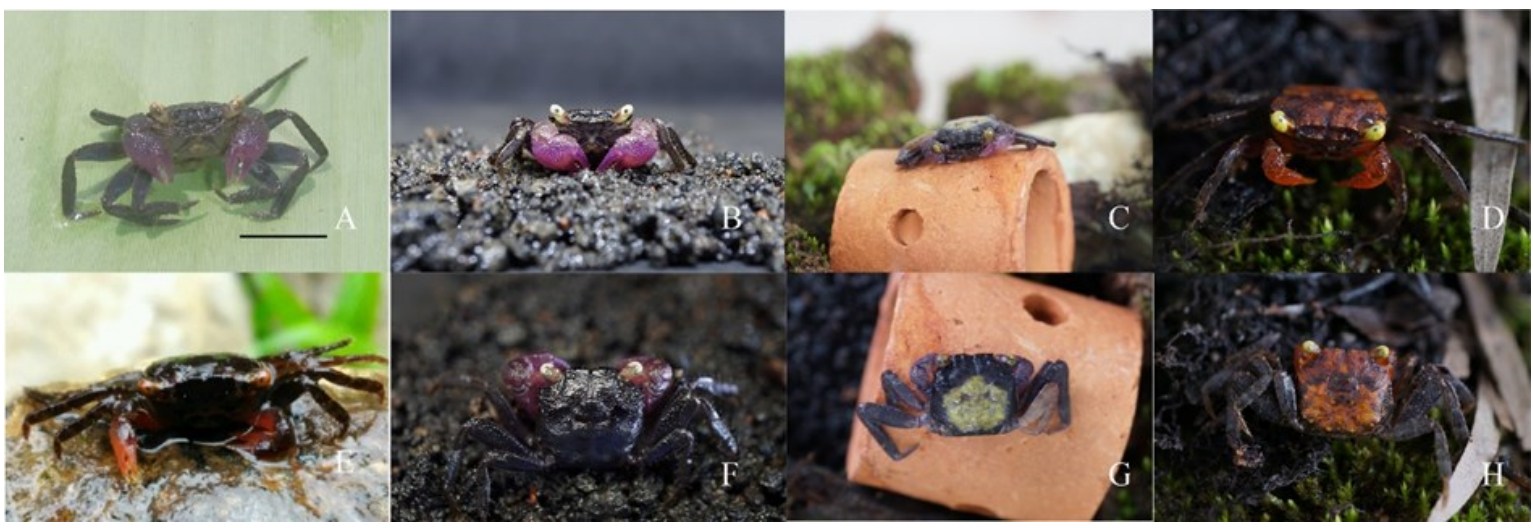

Gambar 2. A, E Jantan capit ungu $(9,80 \times 10,7 \mathrm{~mm})$ dan betina capit jingga $(7,25 \times 8,05 \mathrm{~mm})$ Geosesarma sp. (MZB Cru 5195); B, F jantan $(10,85 \times 11,75 \mathrm{~mm})$ G. noduliferum (MZB Cru 5229); C, G jantan $(9,55 \times 10,65 \mathrm{~mm}) \mathrm{G}$. dennerle dibeli dari dari toko kepiting hias (MZB Cru 5236); D, H betina $(10,5 \times 11,95 \mathrm{~mm}) \mathrm{G}$. hagen dibeli dari toko kepiting hias (MZB Cru 5235). A, E Foto oleh Karso; B-D, F-H foto oleh Hernawati.

yang kaku. Pasangan maksiliped ketiga membentuk celah ketika menutup. Daerah pterigostomial memiliki setae yang padat. Abdomen jantan berbentuk segitiga, sedangkan abdomen betina membulat. Palpus mandibula memiliki ujung satu lobus. Distribusi. Distribusi Marga Geosesarma tersebar luas yaitu di Thailand, Malaysia, Indonesia (Sumatra, Bintan, Jawa, Bali, \& Halmahera), Taiwan dan Filipina (Cai \& Ng 2001; Manuel-Santos et al. 2007; ManuelSantos et al. 2016; Naruse \& Jaafar 2009; Ng 1992; Ng \& Naiyanetr 1992; Ng 1995; Ng \& Tan 1995; Ng \& Davie 1995; Ng et. al. 2004; Ng 2017).

Catatan. Terdapat dua warna mencolok pada sampel kepiting yang ditemukan, yaitu warna karapaks hitam atau sedikit abu keunguan, capit ungu dengan mata kuning dan karapaks hitam, capit jingga dengan mata berwarna jingga. Keduanya memiliki jumlah tonjolan tuberkel 7-9 pada daktilus. Berdasarkan pengamatan di lapang, warna capit jingga nampaknya terdapat pada spesimen betina yang biasanya berukuran kecil. Geosesarma sp. bercapit jingga mirip dengan G. hagen dari Kabupaten Cilacap berdasarkan jumlah tonjolan pada daktilus adalah 7-9 $(\mathrm{Ng}$ et al.
2015). Akan tetapi, karapaks G. hagen berwarna jingga mencolok sedangkan karapaks Geosesarma sp. capit jingga dari Gunung Slamet berwarna hitam sepenuhnya.

Geosesarma sp. bercapit ungu sangat mirip dengan $G$. noduliferum dari Bogor yang juga mempunyai capit ungu dan karapaks hitam dan keunguan di sela-sela pangkal kaki jalan, tetapi bisa dibedakan berdasarkan jumlah tonjolan pada daktilus capit yang berjumlah 7-9 pada Geosesarma sp. vs 11-13 pada G. noduliferum (Ng \& Wowor 2019) dan daerah $\mathrm{H}$ sampai karapaks bawah pada $G$. noduliferum licin sedangkan Geosesarma sp. kasar. Selain itu, penampakan depan Geosesarma sp. juga mirip $G$. dennerle dari Kabupaten Cilacap dengan mata kuning dan capit ungu, tetapi karapaks $G$. dennerle memiliki dua pola warna yang jelas terpisah yaitu ungu dan kuning sedangkan Geosesarma sp. berwarna satu pola warna hitam atau terkadang hitam bergradasi keunguan (Gambar 2.). Berdasarkan Ng \& Wowor (2019), ukuran jantan capit ungu terbesar Geosesarma sp. $(9,80 \times 10,7 \mathrm{~mm})$ lebih kecil dari holotipe jantan $G$. dennerle $(14.4 \times 14.0$ $\mathrm{mm})$, holotype jantan $G$. hagen $(13.9 \times 13.3$ 
$\mathrm{mm})(\mathrm{Ng}$ et al. 2015), dan ukuran jantan terbesar G. noduliferum $(14.5 \times 13.5 \mathrm{~mm})$.

Jenis ini hanya ditemukan pada ketinggian $787 \mathrm{~m}$ dpl. ketika sedang berjalanjalan di hamparan tanaman selada air atau tidak di dalam air sepenuhnya, sehingga Geosesarma dapat disebut kepiting air tawar semiterrestrial. Beberapa ditemukan di balik batu kecil berukuran $<10 \mathrm{~cm}$ (Gambar 5C), selain itu jenis ini juga ditemukan menggerombol.

Kepiting Marga Geosesarma merupakan kepiting yang biasa diperjualbelikan sebagai kepiting hias. Kepastian jenis Geosesarma sp. capit ungu dan Geosesarma sp. capit jingga yang ditemukan pada penelitian ini akan dikonfirmasi lebih lanjut menggunakan DNA barcoding sedang dilakukan (Hernawati, dalam persiapan).

Suku Potamidae Ortmann, 1896 Malayopotamon lipkei Wowor \& Tan, 2010 Gambar 3. A

Malayopotamon lipkei Wowor \& Tan, 2010: 729-731, gb. 1. A-C, 2. A., 3.
Material: 1 jantan $(24,30 \times 29,10 \mathrm{~mm}), 1$ betina $(31,70 \times 38,85 \mathrm{~mm})$, Sungai Banjaran, lokasi 3, Desa Kedungbanteng, Kecamatan Kedungbanteng, Kabupaten Banyumas, Jawa Tengah. 7 Februari 2014, kolektor: R.T. Hernawati \& I.Y. Prasetyo (MZB Cru 5189). 2 betina $(20,70 \times 24,70 \& 24,50 \times 29,60 \mathrm{~mm})$ Sungai Banjaran, lokasi 4, Kalipagu, Desa Ketenger, 8 Februari 2014, kolektor: R.T. Hernawati \& I.Y. Prasetyo (MZB Cru 5190). 1 jantan $(31,70 \times 39,80 \mathrm{~mm}), 1$ betina $(28,30 \times$ 35,45 mm), lokasi 5, Kalipagu, Desa Ketenger, 8 Februari 2014, kolektor: R.T. Hernawati, I.Y. Prasetyo \& Karso (MZB Cru 5191). 1 betina $(30,00 \times 37,15 \mathrm{~mm})$, Sungai Banjaran, lokasi 6, Kalipagu, Desa Ketenger, 9 Februari 2014, kolektor: R.T. Hernawati, I.Y. Prasetyo \& Karso (MZB Cru 5192). 1 betina $(21,90 \times 26,15 \mathrm{~mm})$ anak Sungai Banjaran, lokasi 7, Kalipagu, Desa Ketenger, 9 Februari 2014, kolektor: R.T. Hernawati, I.Y. Prasetyo \& Karso (MZB Cru 5193). 1 jantan $(28,45 \times 35,20 \mathrm{~mm})$, anak Sungai Banjaran (Batur Semende), lokasi 9, Kalipagu, Desa Ketenger. 9 Februari 2014, kolektor:

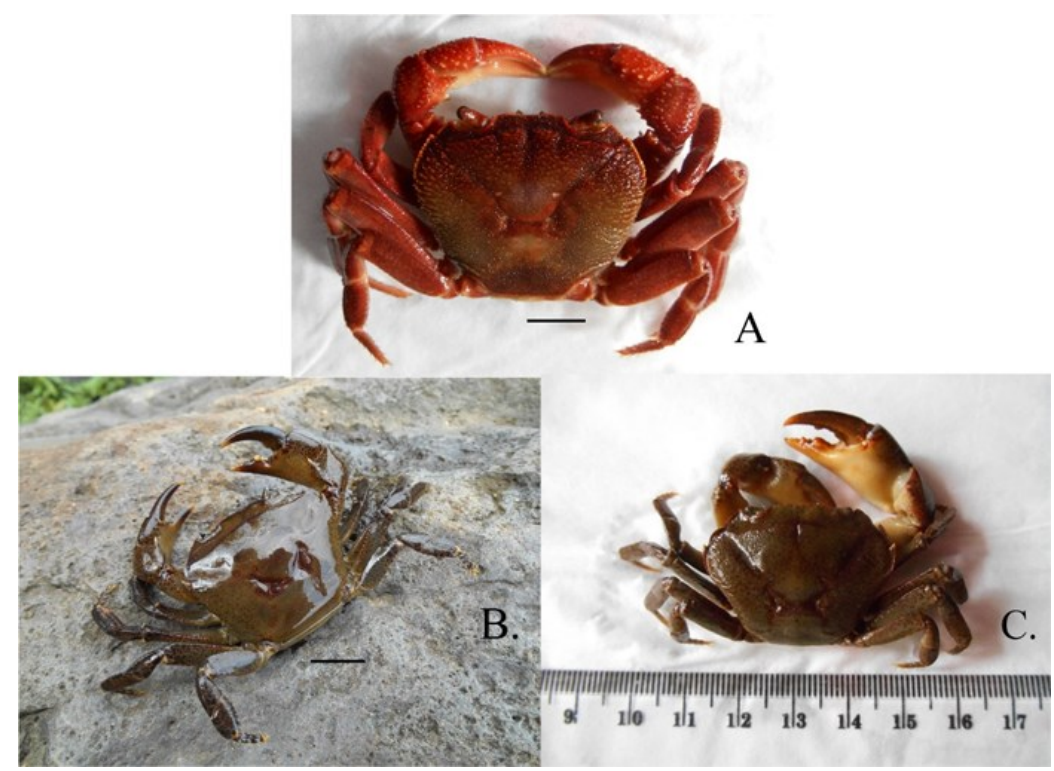

Gambar 3. A Jantan Malayopotamon lipkei $(28,45 \times 35,20 \mathrm{~mm})$ (MZB Cru 5194), B betina Parathelphusa bogorensis $(31 \times 38,6 \mathrm{~mm})$ (MZB Cru 5187), C jantan P. convexa (23 $\times 30,25 \mathrm{~mm}$ ) (MZB Cru 5188). Skala: $1 \mathrm{~cm}$. Foto A-C oleh R.T. Hernawati. 
R.T. Hernawati, I.Y. Prasetyo \& Karso (MZB Cru 5194). Lokasi 4 - lokasi 9 berada di Kecamatan Baturraden, Kabupaten Banyumas, Provinsi Jawa Tengah.

Material pembanding. Malayopotamon lipkei holotype: male $(43.6 \times 37.7 \mathrm{~mm})(\mathrm{MZB}$ Cru 2902).

Diagnosis. Karapaks berbentuk oval menyilang seperti trapesium dengan permukaan datar dan terdapat banyak kerutan atau granul di anterolateral sampai bagian branchial. Memiliki dua gigi/duri pada epibrachial termasuk gigi pada orbit luar mata. Merus pada kaki jalan tidak memiliki duri. Pasangan maksiliped ketiga tidak membentuk celah ketika menutup. Daerah pterigostomial memiliki setae tersebar, tetapi memiliki banyak tonjolan. Abdomen jantan berbentuk segitiga, sedangkan abdomen betina membulat. Palpus mandibula memiliki ujung satu lobus.

Distribusi. Sejauh ini hanya di ketahui berada di lereng selatan G. Slamet. Pada penelitian ini kepiting ditemukan pada 286-800 m dpl di Sungai Banjaran dan anak sungai diatasnya. Pertama kali ditemukan di sungai Dusun Kalipagu, Desa Ketenger pada ketinggian 670780 m dpl (Wowor \& Tan 2010).

Catatan. Malayopotamon lipkei yang ditemukan pada ketinggian $286 \mathrm{~m}$ dpl. mempunyai karapas lunak setelah berganti kulit (molting) dan berwarna merah muda. Pada individu dewasa yang ditemukan di sungai lebar dan berbatu besar (lokasi 3, 4, 5, 6, dan 9), karapaks, kaki jalan, dan capit berwarna coklat keunguan-kemerahan mencolok, sedangkan yang ditemukan di aliran-aliran anak sungai bersubstrat lumpur berpasir, karapaks dan kaki jalan cenderung lebih dominan coklat (lokasi 7). Warna tubuh kepiting ini bisa berbeda berdasarkan substrat dan beberapa tahapan hidupnya karena hal itu merupakan strategi umum untuk mecocokkan warna atau pola diri dengan lingkungan yang biasanya bertujuan untuk menghindari predator (Price dkk. 2019; Stevens dkk. 2014). Malayopotamon lipkei ditangkap menggunakan pancing dengan umpan cacing dan bekicot karena kepiting ini merupakan kepiting yang paling agresif dibandingkan yang lainnya sehingga sulit ditangkap langsung dengan tangan. Selain itu, M. lipkei juga ditemukan di substrat pasir dan batu berukuran 10-50 cm bervariasi, kanopi bambu, di bawah batu sekitar tanaman selada air dan beberapa lokasi tanpa kanopi serta ditemukan sepenuhnya di dalam air (Gambar 5. B).

\section{Suku Gecarcinucidae Rathbun, 1904 \\ Parathelphusa bogorensis Bott, 1970}

Gambar 3. B

Parathelphusa (Parathelphusa) bogorensis Bott, 1970: 122-123, Taf. 23 Fig. 72-74; Taf. 31 Fig. 91.

Material. 1 betina $(9,5 \times 17,55 \mathrm{~mm})(\mathrm{MZB}$ Cru 5186), Sungai Banjaran, lokasi 1, Desa Bobosan, Kecamatan Purwokerto Utara, Kabupaten Banyumas, Jawa Tengah. 7 Februari 2014, kolektor: R.T Hernawati \& Imam. 1 betina $(31 \times 38,6 \mathrm{~mm})(\mathrm{MZB}$ Cru 5187), Sungai Banjaran, lokasi 2, Desa Beji, Kecamatan Kedungbanteng, Kabupaten Banyumas, Jawa Tengah. 7 Februari 2014, kolektor: R.T. Hernawati \& I.Y. Prasetyo.

Material Pembanding. Parathelphusa bogorensis Provinsi Banten 9 jantan $(16,95 \times 21,40-$ $29,75 \times 37,80 \mathrm{~mm}) 8$ betina $(9,60 \times 18,10-$ $23,75 \times 29,70 \mathrm{~mm}) 1$ anakan $(1,00 \times 12,40$ mm) (MZB Cru 4569) dari Kabupaten Lebak. Provinsi Jawa Barat: 1 jantan $(36,95 \times 49,75$ 
mm) 1 betina $(48,00 \times 63,8 \mathrm{~mm})($ MZB Cru 123) dari Tjibarangbrang, Djasinga, Kabupaten Bogor; 1 betina $(28,90 \times 37,65$ mm) (MZB Cru 1197) dari Kabupaten Sukabumi; 2 jantan $(31,00 \times 39,85-33,25 \times$ $41,8 \mathrm{~mm}) 2$ betina $(24,40 \times 30,20 \mathrm{~mm} \& 27,9$ $\times 34,30 \mathrm{~mm})($ MZB Cru 3401) dari Kota Bogor; 1 individu hancur (Cru 1192) dari Kabupaten Garut. Provinsi Jawa Tengah 3 betina $(27,85 \times 22,75-20,10 \times 24,80 \mathrm{~mm})$ (MZB Cru 1225) dari Kabupaten Wonosobo; 1 jantan $(23,95 \times 31,10 \mathrm{~mm}) 1$ betina $(22,60 \times$ 29,00 mm) (MZB Cru 1205) dari Kabupaten Jepara; 2 betina $(18,55 \times 23,50 \& 20,20 \times$ 25,00 mm) (MZB Cru 4742) dari Kabupaten Purworejo. Provinsi Daerah Istimewa Yogyakarta 1 jantan $(42,30 \times 56,10 \mathrm{~mm})$ (MZB Cru 4761) dari Kabupaten Kulon Progo. Provinsi Jawa Timur 1 jantan $(25,00 \times$ 31,80 mm) (MZB Cru 1222) dari Kabupaten Malang; 1 betina $(23,80 \times 30,40 \mathrm{~mm})(\mathrm{MZB}$ Cru 3051) dari Kabupaten Tuban; 1 jantan $(29,30 \times 23,85 \mathrm{~mm})($ MZB Cru 1195) dari Kabupaten Trenggalek. Provinsi Bali 3 jantan $(16,65 \times 20,15-25,4 \times 31,85 \mathrm{~mm}) 5$ betina $(16 \times 19,8-29,7 \times 37,70 \mathrm{~mm})($ MZB Cru 471) dari Kabupaten Bangli.

Diagnosis. Karapaks berbentuk oval menyilang seperti trapesium dengan permukaan datar. Kerutan terdapat di daerah metabranchial, mesobranchial dan sedikit pada epibranchial. Memiliki 3 gigi/duri pada pada epibrachial termasuk gigi pada orbit luar mata. Merus pada kaki jalan tidak memiliki duri. Pasangan maksiliped ketiga tidak membentuk celah ketika menutup. Daerah pterigostomial pterigostomial tidak memiliki setae atau gundul, tetapi memiliki tonjolan yang tersebar. Abdomen jantan berbentuk $T$, sedangkan betina membulat. Palpus mandibula berujung dua lobus.
Distribusi. Parathelphusa bogorensis ditemukan di Provinsi Banten: Kabupaten Lebak; Provinsi Jawa Barat: Kabupaten Bogor, Indramayu, Garut, Sukabumi dan Kota Bogor; Provinsi Jawa Tengah: Kabupaten Banyumas, Cilacap, Djelok, Jepara, Purworejo, Salatiga, dan Wonosobo; Provinsi Daerah Istimewa Yogyakarta: Kabupaten Kulon Progo; Provinsi Jawa Timur: Kabupaten Pacitan, Malang, Trenggalek, dan Tuban; Provinsi Bali: Kabupaten Bangli (Bott 1970; Koleksi MZB; Hernawati dkk. 2013; Hernawati unpublish; Wowor 2010).

Catatan. Parathelphusa bogorensis merupakan krustasea yang biasanya terdapat di daerah hulu dan penghuni sungai berarus deras (Wowor 2010). Jenis ini ditemukan pada ketinggian $1524 \mathrm{~m}$ dpl. di Gunung Arjuna Kabupaten Pacitan (Bott 1970), sedangkan di Gunung Slamet ditemukan pada substrat pasir, batu berukuran kurang dari $10 \mathrm{~cm}$, sepenuhnya di dalam air dan kanopi bambu pada ketinggian 105-195 m dpl. (Gambar 5. A). Lebar karapaks $(38,6 \mathrm{~mm})$ dibandingkan tebal karapas $(13,7 \mathrm{~mm})$ sekitar 2,8 kali, sedangkan $P$. convexa sekitar 2,5 kali. Warna karapaks dan kaki jalan adalah coklat kehijauan, sedangkan ujung capit berwarna kekuningan.

\section{Parathelphusa convexa (De Man 1879)} Gambar 3. C

Parathelphusa (Parathelphusa) convexa - Bott 1970: 121-122, Taf. 23 Fig. 69-71, Taf. 31 Fig. 90.

Material. 6 jantan $(9,10 \times 11-23 \times 30,25$ $\mathrm{mm}), 6$ betina $(8,1 \times 9,4-15,9 \times 20,1 \mathrm{~mm}), 3$ anakan $(4,75 \times 6,40-6,25 \times 7,00 \mathrm{~mm})$, Sungai Banjaran, lokasi 1, Desa Bobosan, Kecamatan Purwokerto Utara, Kabupaten Banyumas, Jawa Tengah, 7 Februari 2014, 
kolektor: R.T. Hernawati \& I.Y. Prasetyo (MZB Cru 5188).

Material Pembanding. Provinsi Lampung 2 jantan $(9,45 \times 11,25 \mathrm{~mm} \& 30,05 \times 41,55$ mm) 3 betina $(18,80 \times 24,65-25,90 \times 35,15$ mm) (MZB Cru 1215) dari Kabupaten Lampung Timur; 10 jantan $(7,00 \times 8,75$ $16,90 \times 21,40 \mathrm{~mm}) 10$ betina $(12,55 \times 15,70$ - 17,80 × 23,20 mm) (MZB Cru 077) dari Kabupaten Pesawaran. Daerah Khusus Ibukota Jakarta 2 jantan $(23,90 \times 32,15 \& 36,1 \times 34,10$ mm) (MZB Cru 3017) dari Jakarta Jakarta Selatan. Provinsi Banten 1 jantan $(8,60 \times$ $11,10 \mathrm{~mm}) 3$ betina $(9,30 \times 11-24,70 \times 32,85$ mm) (MZB Cru 3102) dari Kabupaten Tanggerang; 3 jantan $(12,00 \times 14,70-20,10 \times$ $26,25 \mathrm{~mm}) 1$ betina $(20,75 \times 21,40 \mathrm{~mm}) 6$ anakan $(17,70 \times 8,75-10,00 \times 12,05 \mathrm{~mm})$ (MZB Cru 4579) dari Kabupaten Lebak. Provinsi Jawa Barat 3 jantan $(9,15 \times 10,65-$ $25,15 \times 32,85 \mathrm{~mm}) 2$ betina $(13,50 \times 16,35$ $\mathrm{mm} \& 21,45 \times 28,00 \mathrm{~mm})($ MZB Cru 027) Kabupaten Garut; 2 jantan $(20,65 \times 26,95 \mathrm{~mm}$ $\& 23,20 \times 31,20 \mathrm{~mm}) 1$ betina $(23,70 \times 30,85$ mm) (MZB Cru 4578) dari Kabupaten Sukabumi; 1 jantan $(26,70 \times 35,90 \mathrm{~mm}) 1$ betina $(30,50 \times 41,10 \mathrm{~mm})($ MZB Cru 3103) dari Kabupaten Bogor; 1 jantan $(19,20 \times 24,50$ mm) (MZB Cru 3030) dari Kota Depok; 2 jantan $(20,00 \times 27,40 \& 23,05 \times 31,35 \mathrm{~mm})$ (MZB Cru 1211) dari Kabupaten Bandung Barat; 1 betina $(12,65 \times 15,55 \mathrm{~mm})(\mathrm{MZB}$ Cru 1188) dari Kota Cimahi; 1 jantan $(10,25 \times$ $12,85 \mathrm{~mm}) 1$ betina $(12,55 \times 15,60 \mathrm{~mm})$ (MZB Cru 1241) dari Kabupaten Indramayu. Provinsi Jawa Tengah 3 jantan $(19,85 \times 25,15$ $-21,20 \times 26,95 \mathrm{~mm}) 8$ betina $(16,00 \times 21,25-$ $27,80 \times 36,20 \mathrm{~mm})($ MZB Cru 2562) dari Kabupaten Wonogiri; 1 jantan $(19,30 \times 25,25$ $\mathrm{mm}) 1$ betina $(21,70 \times 28,75 \mathrm{~mm})($ MZB Cru
4737) dari Kabupaten Purworejo; 4 jantan $(13,60 \times 16,66-21,75 \times 28,45 \mathrm{~mm})(\mathrm{MZB}$ Cru 4980) dari Kabupaten Magelang; 1 jantan $(29,60 \times 40,15 \mathrm{~mm}) 1$ betina $(15,95 \times 20,65$ mm) (MZB Cru 1183) dari Kabupaten Semarang; 2 jantan $(12,95 \times 15,75 \& 22,50 \times$ 29,30 mm) (MZB Cru 1242) dari Kabupaten Jepara; 2 betina $(11,15 \times 13,60 \& 11,10 \times$ 14,25 mm) (MZB Cru 484) dari Kabupaten Kudus. Provinsi Daerah Istimewa Yogyakarta 2 jantan $(17,05 \times 20,75 \mathrm{~mm} \& 21,00 \times 27,05$ mm) (MZB Cru 1596) dari Kabupaten Gunung Kidul; 1 jantan $(19,80 \times 26,45 \mathrm{~mm})$ (MZB Cru 4981) dari Kabupaten Kulon Progo. Provinsi Jawa Timur 3 jantan $(13,00 \times$ $16,45-19,35 \times 21,65 \mathrm{~mm}) 1$ betina $(26,00 \times$ 34,60 mm) (MZB Cru 5238) dari Kabupaten Malang; 9 jantan $(8,65 \times 16,60-28,35 \times$ $38,50 \mathrm{~mm}) 8$ betina $(14,70 \times 17,75-27,50 \times$ 36 mm) (MZB Cru 4091) dari Kabupaten Pacitan; 1 betina $(23,05 \times 29,05 \mathrm{~mm})($ MZB Cru 3938) dari Kabupaten Lumajang; 1 jantan $(15,65 \times 19,90 \mathrm{~mm}) 1$ betina $(35,65 \times 46,70$ mm) (MZB Cru 3045) dari Kabupaten Tuban; 2 jantan $(9,60 \times 19,15 \& 26,25 \times 36,25 \mathrm{~mm})$ (MZB Cru 473) dari Kabupaten Sidoarjo; 1 jantan $(23,00 \times 30,70 \mathrm{~mm})($ MZB Cru 052) dari Kabupaten Bondowoso.

Diagnosis. Karapaks berbentuk oval menyilang seperti trapesium dengan permukaan sedikit meninggi. Kerutan terdapat di daerah metabranchial, mesobranchial dan sedikit pada epibranchial. Memiliki 3 gigi/duri pada epibrachial termasuk gigi pada orbit luar mata. Merus pada kaki jalan memiliki duri. Pasangan maksiliped ketiga tidak membentuk celah ketika menutup. Daerah pterigostomial tidak memiliki setae atau gundul, tetapi memiliki tonjolan yang tersebar. Abdomen jantan berbentuk $T$, sedangkan betina 
membulat. Palpus mandibula berujung dua lobus.

Distribusi. Parathelphusa convexa ditemukan di Provinsi Lampung: Kabupaten Lampung Timur dan Pesawaran; DKI Jakarta di Jakarta Selatan; Provinsi Banten: Kabupaten Lebak dan Tanggerang; Provinsi Jawa Barat: Kabupaten Bandung Barat, Bogor, Garut, Indramayu, Sukabumi, Kota Depok, dan Kota Cimahi; Provinsi Jawa Tengah: Kabupaten Cilacap, Jepara, Kudus, Magelang, Purworejo, Semarang, dan Wonogiri; Provinsi Daerah Istimewa Yogyakarta: Kabupaten Gunung Kidul dan Kulon Progo; Provinsi Jawa Timur: Kabupaten Bondowoso, Lumajang, Malang, Pacitan, Sidoarjo, dan Tuban (Koleksi MZB; Hernawati dkk. 2013; Wowor 2010).

Catatan. Jenis ini mirip dengan $P$. bogoriensis yaitu memiliki karapaks berbentuk trapesium, abdomen jantan berbentuk $\mathrm{T}$, palpus mandibular berujung dua lobus. Akan tetapi, memiliki perbedaan pada kaki jalan yang berduri pada $P$. convexa, sedangkan pada $P$. bogorensis kaki jalan tanpa duri. Spesimen terbesar jantan memiliki lebar karapaks $(30,25 \mathrm{~mm})$ dibandingkan tebal karapaks $(11,8 \mathrm{~mm})$ sekitar 2,5 kali, sedangkan P. bogorensis 2,8 kali. Spesimen dikoleksi di Sungai Banjaran dengan arus yang lebih lambat, substrat pasir, batu berukuran kurang dari $10 \mathrm{~cm}$, sepenuhnya di dalam air dan kanopi bambu pada ketinggian $105 \mathrm{~m}$ dpl. (Gambar 5 A), sedangkan catatan koleksi Museum Zoologicum Bogoriense ditemukan pada ketinggian $986 \mathrm{~m}$ dpl. Di Situ Cisangku Kabupaten Bogor (MZB Cru 3103).

\section{Terrathelphusa sp.}

Gambar 4. C

Material. 2 betina $(16,35 \times 21,3 \& 19,35 \times$ 24,55 mm), anak sungai Banjaran, lokasi 10, Kalipagu, Desa Ketenger, 9 Februari 2014, kolektor: R.T. Hernawati, I.Y. Prasetyo \& Karso (MZB Cru 5196). 1 jantan $(13,65 \times$

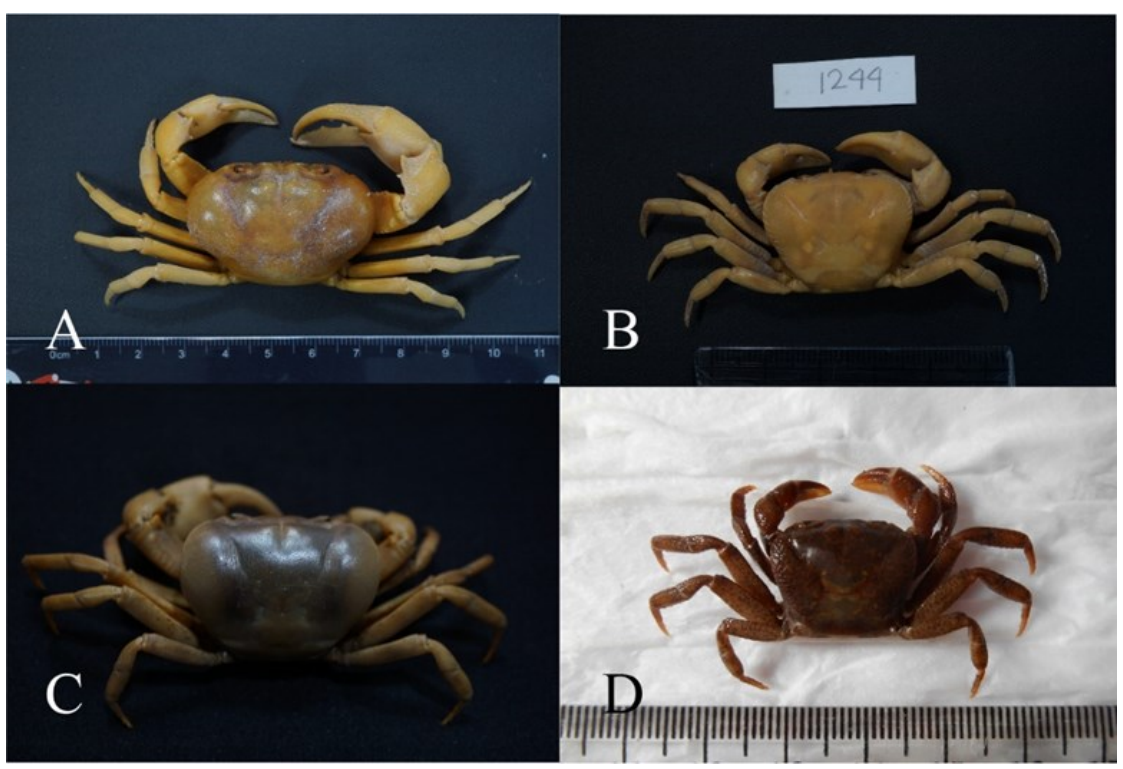

Gambar 4. A. Terrathelphusa chilensis $(30,95 \times 42,90 \mathrm{~mm})$ dari Tanggerang, Banten (MZB Cru 1213) dalam Ng (1989); B. Jantan $(19,60 \times 25,45 \mathrm{~mm})$ T. kuhli dari Sancang, Jawa Barat (MZB Cru 1244) dalam Ng (1989); C. Jantan T. chilensis $(28,80 \times 39,45 \mathrm{~mm})$ dari Cilacap, Jawa Tengah, (MZB 5198) bersebelahan dengan Kabupaten Banyumas; D. Jantan Terrathelphusa sp. $(13,65 \times 16,8 \mathrm{~mm})$ dari Gunung Slamet Banyumas, Jawa Tengah (MZB Cru 5197) di penelitian ini. Foto A-B diambil oleh D.A. Nugroho, C-D diambil oleh R.T. Hernawati. 
16,8 mm), anak sungai Banjaran, lokasi 12, Kalipagu, Desa Ketenger, 9 Februari 2014, kolektor: R.T. Hernawati, I.Y. Prasetyo \& Karso (MZB Cru 5197). Kedua lokasi berada di Kecamatan Baturraden, Kabupaten Banyumas, Provinsi Jawa Tengah.

Material pembanding. 1 jantan $T$. kuhli $(19,60 \times 25,45 \mathrm{~mm})$ dari Sancang, Jawa Barat (MZB Cru 1244) yang telah ditulis dalam Ng (1989). 1 jantan T. chilensis $(27,05 \times 39,2$ $\mathrm{mm}), 1$ betina $(30,95 \times 42,90 \mathrm{~mm})$, Desa Kresek, Karawang, Jawa Barat, Banten (MZB Cru 1213) yang telah ditulis dalam Ng (1989). 21 jantan $(30,40 \times 41,40-17,40 \times 23,15 \mathrm{~mm})$, 12 betina $(19,05 \times 24,40-30,00 \times 40,30 \mathrm{~mm})$ Terrathelphusa chilensis dari Cilacap, Jawa Tengah, (MZB Cru 5198).

Diagnosis. Karapaks berbentuk oval menyilang seperti trapezium dan agak menggembung. Kerutan terdapat di seluruh bagian branchial (epibrachial, mesobranchial dan metabranchial). Memiliki 2 gigi/duri pada epibrachial termasuk gigi orbit luar mata. Merus pada kaki jalan tidak memiliki gigi tajam. Pasangan maksiliped ketiga tidak membentuk celah ketika menutup. Daerah pterigostomial memiliki sedikit sekali setae yang sangat pendek dan tersebar, tetapi memiliki tonjolan yang mengumpul. Abdomen jantan berbentuk $\mathrm{T}$, sedangkan betina berbentuk segitiga. Palpus mandibula berujung dua lobus.

Distribusi. Di Pulau Jawa Marga Terrathelphusa ditemukan di Jawa Barat: Kabupaten Bogor, Sukabumi, Banten dan Indramayu; Jawa Tengah: Kabupaten Cilacap, Banyumas. (Koleksi MZB; Hernawati unpublish; Ng 1898).

Catatan. Terdapat dua jenis kepiting Marga Terrathelphusa di Pulau Jawa, yaitu:
T. chilensis (Heller, 1862) yang merupakan jenis yang biasanya hidup di dataran rendah dan tercatat keberadaannya di Banyumas dan Tanggerang (Ng 1989) (Gambar 4A), sedangkan T. kuhli (de Man, 1883) merupakan jenis yang ditemukan di dataran tinggi pegunungan, sebelumnya tercatat di Gunung Gede, Cibodas dan Sancang, Jawa Barat (Gambar 4B) (Ng 1989; Ng \& Wowor 2018). Keduanya memiliki karapaks yang menggembung, namun $T$. chilensis memiliki gigi anterolateral yang sangat rendah dibandingkan $T$. kuhli. Terrathephusa chilensis memiliki karapaks yang licin atau kerutan tipis, sedangkan T. kuhli memiliki kerutan yang nyata pada anterolateral. Warna hidup $T$. chilensis umumnya kuning muda hingga coklat muda, sedangkan $T$. kuhli berwarna merah keunguan mencolok untuk jantan dan coklat putih untuk betina $(\mathrm{Ng}$ 1989).

Spesimen Terrathelphusa sp. lebih dekat dengan T. kuhli karena sama memiliki gigi yang jelas. pada ketinggian $1400 \mathrm{~m}$ dpl. pada substrat lumpur lembut di Gunung Gede. Begitu pula dengan Ng (1989) mengidentifikasi sampel dari Baturraden pada ketinggian 1000 $\mathrm{m}$ asl sebagai T. kuhli. Namun, beberapa karakter yang membedakan dari Terrathelphusa sp. dari Gunung Slamet dengan T. kuhli di Cibodas, Gunung Gede dan Sancang (Ng 1989), diantaranya spesimen dari Gunung Slamet memiliki lebih banyak kerutan pada daerah tepi epibranchia (Gambar 4. A vs 4. C) 1; segment distal dari G2 panjang sekitar 0,67 kali panjang segmen dasar vs. 0,35 kali $(\mathrm{Ng}$ 1989). Spesimen jantan Terrathelphusa sp. memiliki karapaks yang lebih ramping atau hampir kotak (Gambar 4. D) dibandingkan karapaks $T$. kuhli jantan dari Sancang yang 


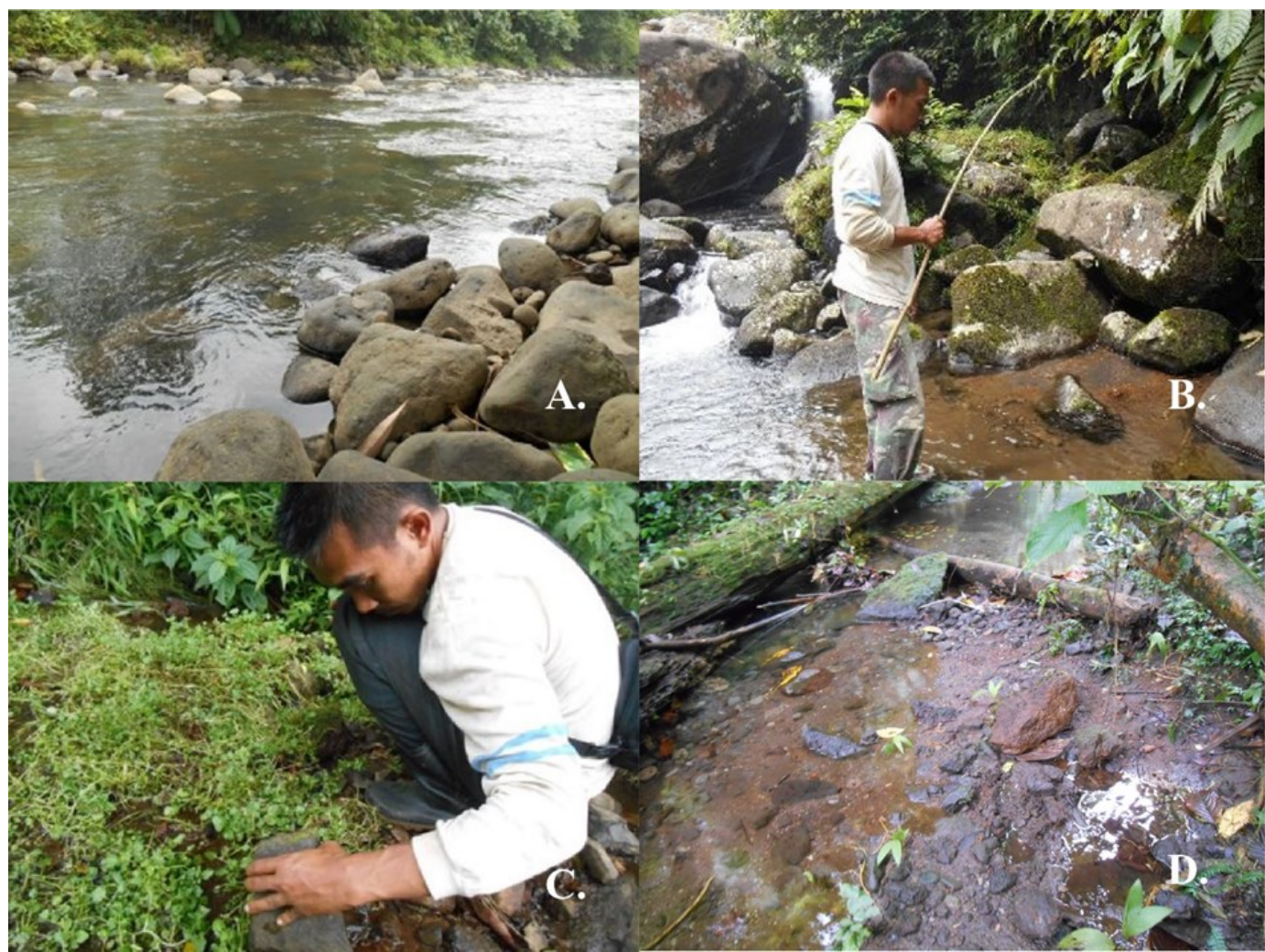

Gambar 5. A. Lokasi ditemukannya Parathelphusa bogorensis dan Parathelphusa convexa di ketinggian $105 \mathrm{~m}$ dpl di Sungai Banjaran; B. Lokasi ditemukannya Malayopotamon lipkei di ketinggian $560 \mathrm{~m}$ dpl. Sungai Banjaran; C. Lokasi ditemukannya Geosesarma sp. di ketinggian $787 \mathrm{~m}$ dpl. di hamparan tanaman selada air; D. Lokasi ditemukannya Terrathelphusa sp.di ketinggian $997 \mathrm{~m}$ dpl. anak sungai diatas Sungai Banjaran. Foto A-D diambil oleh R.T. Hernawati.

cenderung seperti bentuk hati (Gambar 4. B) ataupun karapaks spesimen jantan dari Cibodas yang sangat menggembung di bagian lateral (Ng \& Wowor 2018). Kepiting yang berada di Gunung Slamet berwarna coklat kekuningan hingga coklat tua dengan capit putih kejinggaan, sedangkan di Gunung Gede berwarna merah keunguan mencolok untuk jantan dan coklat putih untuk betina $(\mathrm{Ng}$ 1989). Kerutan Terrathelphusa sp. terdapat di seluruh bagian branchial (epibrachial, mesobranchial dan metabranchial) nampak jelas, sedangkan di Terrathelphusa kuhli lebih rendah atau tipis. Tonjolan di daerah pterigostomial Terrathelphusa sp. lebih padat dan mengumpul mendekati bagian bawah, sedangkan tonjolan pada Terrathelphusa kuhli lebih tipis, sedikit dan tersebar dibagian tengah.
Terrathelphusa sp. pada penelitian ini ditemukan pada aliran anak sungai kecil di atas Sungai Banjaran pada lereng selatan Gunung Slamet di ketinggian 916-997 m dpl. Jenis ini ditemukan di pinggiran aliran anak sungai berkanopi lebat, bersubstrat tanah dan ditemukan bawah batu tanpa air menggenanginya sehingga jenis ini disebut kepiting darat atau terrestrial (Gambar 5. D). Penelitian lanjutan berdasarkan molekuler (DNA) perlu dilakukan untuk memastikan jenis dari Jawa Barat dan Jawa Tengah tersebut.

\section{Kunci identifikasi kepiting air tawar di lereng selatan Gunung Slamet:}

Identifikasi kepiting air tawar terutama menggunakan kepiting jantan. Bentuk 
gonopod sangat penting dalam menentukan jenis kepiting karena morfologi dari kepiting sungai cenderung konservatif (Cumberlidge 1999). Karakter lain yang penting dalam identifikasi kepiting sungai jantan diantaranya bentuk karapaks, perbandingan mata dengan karapaks, gigi pada karapaks, lobus mandibula palp, celah, dan bentuk pada maxiiliped ketiga, daerah pterigostomial, bentuk abdomen jantan, dan duri pada kaki jalan (Ng 2004). Kepiting betina diidentifikasi sesuai karakter yang ada dikepiting jantan kecuali bentuk gonopod dan ada tidaknya vulva pada sternopleonal (Ng \& Wowor 2018).

Kunci identifikasi kepiting air tawar lereng selatan Gunung Slamet, Kabupaten Banyumas:

1. - Mata relatif sangat besar untuk ukuran karapaks, kornea mencapai tepi karapaks, karapaks hampir berbentuk persegi, daerah pterigostomial memiliki setae yang padat, ukuran karapaks individu dewasa kecil sekitar 9,75 × 11,1 mm (Gambar A-H) SESARMIDAE: Geosesarma sp.

- Mata relatif kecil untuk ukuran karapaks, kornea tidak mencapai tepi karapaks, karapaks hampir kotak sampai oval menyilang atau trapesium, daerah pterigostomial memiliki setae yang tersebar, tepi anterolateral tak bergerigi atau dengan gigi, lobus atau berduri, ukuran individu dewasa besar sekitar 19,35 × 24,55 mm pada jenis Terrathelphusa sp. dan $31,70 \times$ $38,85 \mathrm{~mm}$ pada jenis lain .2

2. - Palpus mandibula dengan lobus berujung tunggal; abdomen jantan berbentuk segitiga, tonjolan di karapaks menyebar merata pada daerah gastrik dan brachial (Gambar 3
A)....POTAMIDAE: Malayopotamon lipkei

- Palpus mandibula dengan lobus berujung ganda; abdomen jantan berbentuk T GECARCINUCIDAE 3

3. - Gigi di epibrachial berjumlah 2 (termasuk gigi orbit luar pada mata)

- Gigi di epibrachial berjumlah 3 gigi yang nyata (termasuk gigi orbit luar pada mata) .5

4. - Gigi di epibrachial terbentuk jelas, tepi anterolateral karapaks menggembung, daerah brachial (epibracnchial, mesobranchial, dan metabranchial) bergaris dengan kerutan lebih jelas. Terrathelphusa sp.

- Gigi di epibrachial sangat rendah, tepi anterolateral karapaks menggembung, kerutan daerah branchial (hanya pada mesobranchial dan metabranchial) sangat halus atau hampir licin......Terrathelphusa chilensis

5. - Karapaks datar, merus pada semua kaki jalan tidak memiliki duri yang tajam dan jelas di bagian subterminal dorsal

.Parathelphusa bogorensis

- Karapaks sedikit menggembung, merus pada semua kaki jalan memiliki duri tajam dan jelas dibagian subterminal dorsal................Parathelphusa convexa

\section{KESIMPULAN}

Dua jenis yang ditemukan di lereng selatan Gunung Slamet mengisi relung ekologi dan ketinggian yang sama yaitu $P$. bogorensis dan $P$. convexa pada ketinggian $105 \mathrm{~m}$ dpl., sedangkan tiga jenis lain yang ditemukan pada habitat dan ketinggian berbeda, adalah: Geosesarma sp. ditemukan mulai ketinggian 787 m dpl., M. lipkei pada ketinggian 286-800 m dpl., dan Terrathelphusa sp. pada ketinggian 916-997 m dpl. Penelitian ini 
menunjukkan bahwa pemilihan habitat, seperti jenis substrat dan vegetasi yang sangat spesifik pada ketinggian tertentu menentukan distribusi atau keberadaan jenis yang berbeda.

Upaya pengambilan sampel kembali harus dilakukan untuk mengetahui karakterkarakter bentuk dewasa. Selain itu, penelitian dengan menggunakan data molekuler (DNA) perlu dilakukan untuk mendapatkan identifikasi yang akurat bagi Geosesarma sp. dan Terrathelphusa sp. dari Gunung Slamet.

\section{UCAPAN TERIMAKASIH}

Ucapan terima kasih saya ucapkan kepada I.Y. Prasetyo dan Karso yang telah membantu dalam survey penelitian ini. Selain itu, saya juga berterima kasih kepada reviewer yang telah meluangkan waktu untuk menelaah karya ilmiah ini.

\section{DAFTAR PUSTAKA}

Amelia, T., Lestari, W., \& Nuryanto, A. 2014. Distribusi Longitudinal dan Struktur Populasi Rasbora spp. di Sungai Banjaran Kabupaten Banyumas. Scripta Biologica, 1(2),167-172.

Bott, R. 1970. Die süsswasserkrabben von Europa, Asien, Australien und ihre Stammesgeschichte. Eine revision der Potamoidea und der Parathelphusoidea (Crustacea, Decapoda). Abhandlungen der Senckenbergischen Naturforschenden Gesellschaft, Pp.526, 13.

Cai, Y., \& Ng, P. K. L. 2001. The freshwater decapod crustaceans of Halmahera, Indonesia. Journal of Crustacean Biology, 21(3), 665-695.

Cumberlidge, N. 1999. The freshwater crabs of West Africa: Family Potamonautidae.
Editions De L'ird. ISBN 2-7099-1433-6. Pp, 38-40.

Deekae, S. N., \& Abowei, J. F. N. 2010. Some age related attributes of Macrobrachium macrobrachion (Herklots, 1851) from Luubara Creek in Ogoni Land, Niger Delta, Nigeria. Journal of Biological Sciences, 2(5), 313-322.

De Man, J. G. 1892. Decapoden des Indischen Archipels. In: Max. Weber, editor. Zoologischc Ergebnisse einer Reise in Niederlandisch Ost-lndien, (2), 265527.

Esch, R. E., Hartsell, C. J., Crenshaw, R., \& Jacobson, R. S. 2001. Common allergenic pollens, fungi, animals, and Arthropods. Clinical Reviews in Allergy and Immunology, 21, 261-292.

Grinang, J. \& P.K.L. Ng. 2015. The identity of the semiterrestrial crab Terrathelphusa kuchingensis (Nobili, 1901) (Crustacea: Decapoda: Brachyura: Gecarcinucidae), with descriptions of four new species from southwestern Sarawak, Borneo, Malaysia. Zootaxa, 3946 (3), 331-346.

Hernawati, R. T., A. Nuryanto \& Indarmawan. 2013. Kajian Tentang Kekayaan Dan Hubungan Kekerabatan Crustacea (Decapoda) Di Sungai Cijalu Kecamatan Majenang Kabupaten Cilacap. Jurnal Pembangunan Pedesaan, 13(1), $39-48$

Manuel-Santos, M. R. \& Yeo, D. C. J. 2007. A new species of Geosesarma from Palawan, Philippines (Crustacea: Decapoda: Brachyura: Sesarmidae). Zootaxa, 1607, 63-67.

Manuel-Santos, M., Ng, P. K. L. \& Freitag, H. 2016. Two new species of Geosesarma De Man, 1892 (Crustacea: Brachyura: 
Sesarmidae) from Palawan, the Philippines. Raffles Bulletin of Zoology, 64, 335342.

Naruse, T., \& Jaafar, Z. 2009. On a new species of cavernicolous crab of the Genus Sesarmoides Serene and Soh, 1970 (Crustacea: Decapoda: Brachyura: Sesarmidae) from Sulawesi Indonesia. The Raffles Bulletin of Zoology, 57(1), 183-187.

Ng, P. K. L. 1989. Terrathelphusa, a new genus of semiterrestrial freshwater crabs from Borneo and Java (Crustacea: Decapoda: Brachyura: Sundathelphusidae). The Raffles Bulletin of Zoology, 37 (1 \& 2), 116-131.

Ng, P. K. L. 1992. Geosesarma sabanus, a New Sesarmine Crab (Decapoda, Brachyura, Grapsidae) from the Forests of Sabah, East Malaysia, Borneo. Crustaceana, 63(2), 210-310.

Ng, P. K. L., \& P. Naiyanetr. 1992. On a new species of Geosesarma de Man, 1892 (Crustacea: Decapoda: Brachyura: Grapsidae) from Chanthaburi Province, eastern Thailand. Zoologische Mededelingen, 66, 449-452.

Ng, P. K. L. 1995. On one new genus and three new species of freshwater crabs (Crustacea: Decapoda: Brachyura: Potamidae and Grapsidae) from LanjakEntimau, Sarawak, East Malaysia, Borneo. Zool. Med. Leiden, 69, 57-71.

Ng, P. K. L. \& Tan, C.G.S. 1995. Geosesarma notophorum sp. nov. (Decapoda, Brachyura, Grapsidae, Sesarminae), a Terrestrial Crab from Sumatra, with Novel Brooding Behaviour. Crustaceana, 68 (3), 391-395.

Ng, P. K. L. \& Davie, P.J.F. 1995. The terrestrial crabs of the genera Metasesarma and Geosesarma (Crustacea: Decapoda: Brachyura: Grapsidae) of Ujung Kulon, West Jawa, Indonesia. Tropical Biodiversity, 3(1), 29.

Ng, P. K. L. 2004. Crustacea: Decapoda, Brachyura (Freshwater Invertebrate of the Malaysian Region). In Yule, C. M., Sen, Y. H. 2004. Freshwater Invertebrates of the Malaysian Region. Academy of Sciences Malaysia, Kualalumpur.

Ng, P. K. L., Liu, H. C. \& C. D. Schubart. 2004. Geosesarma hednon, a New Species of Terrestrial Crab (Crustacea: Decapoda: Brachyura: Sesarmidae) from Taiwan and the Philippines. The Raffles Bulletin of Zoology, 52(1), 239249.

Naruse, T., \& Z. Jaafar. 2009. Geosesarma aedituens, a new terrestrial crab (Crustacea: Decapoda: Brachyura: Sesarmidae) from Bali, Indonesia. The Raffles Bulletin of Zoology, 57(1), 183187.

Ng, P. K. L., Shih, H. T., Naruse, T., \& Shy, J. Y. 2010. Using molecular tools to establish the type locality and distribution of the endemic taiwanese freshwater crab Geothelphusa chiui Minei, 1974 (Crustacea: Brachyura: Potamidae), with Notes on the Genetic Diversity of Geothelphusa from Eastern Taiwan. Zoological Studies, 49(4), 544-555.

Ng, P. K. L., C. D. Schubart, \& C. Lukhaup. 2015. New species of "vampire crabs" (Geosesarma De Man, 1892) from central Java, Indonesia, and the identity of Sesarma (Geosesarma) nodulifera De Man, 1892 (Crustacea, Brachyura, Thoracotremata, Sesarmidae). 
Raffles Bulletin of Zoology, 63, 3-13. 18. doi:10.1093/jcbiol/ruy016

Ng, P. K. L., \& Wowor, D. 2018. A new genus and new species of a semiterrestrial freshwater crab from montane tropical rainforests in Java, Indonesia (Decapoda: Brachyura: Gecarcinucidae). Journal of Crustacean Biology, 1-8. doi:10.1093/jcbiol/ruy016.

Ng, P. K. L. 2017. On the identities of the highland vampire crabs, Geosesarma foxi (Kemp, 1918) and G. serenei $\mathrm{Ng}$, 1986, with description of a new phytotelmic species from Penang, Peninsular Malaysia (Crustacea: Decapoda: Brachyura: Sesarmidae). Raffles Bulletin of Zoology, 65, 226-242.

Ng, P. K. L., \& Wowor, D. 2019. The vampire crabs of Java, with descriptions of five new species from Mount Halimun Salak National Park, West Java, Indonesia (Crustacea: Brachyura: Sesarmidae: Geosesarma). Raffles Bulletin of Zoology, 67, 217-246.

Price, N., Green, S., Troscianko, J., Tregenza, T. \& Stevens, M. 2019. Background matching and disruptive coloration as habitatspecific strategies for camouflage. Scientific Reports, 9, 7840.

Stevens, M., Lown, A. E., \& Wood, L. E. 2014. Camouflage and Individual Variation in Shore Crabs (Carcinus maenas) from Different Habitats. PLoS ONE, 9, 12.
Serene, P.R. 1967. Note Preliminaire Sur De Nouvelles Especes De Sesarma (Decapoda Brachyura). Bulletin Du Museum National D'Histoire Naturelle, $2 e$ Serie, Tome 39 (6): 1084-1095.

Thiel, M., \& Baeza, J. A. 2001. Factors affecting the social behaviour of Crustaceans living symbiotically with other marine invertebrates: A Modelling Approach. Symbiosis, 30, 163-190.

Van Noordwijk, M., Agus, F., Suprayogo, D., Hairiah, K., Pasya, G, Verbist, B., \& Farida. 2004. Peranan agroforestri dalam mempertahankan fungsi hidrologi daerah aliran sungai (DAS). AGRIVITA, 26,1 .

Whitten, T., Soeriaatmadja, R. E., \& Afiff, S. A. 2013. The Ecology of Java and Bali. New York: Tuttle Publishing.

Wowor, D., \& Tan, S. H. 2010. Description of a new species of Malayopotamon bott, 1968 (decapoda, brachyura, potamidae) from Gunung Slamet, Central Java, Indonesia. Studies on Malacostraca, 727-734.

Wowor, D. 2010. Studi Biota Perairan dan Herpetofauna di Daerah Aliran Sungai (DAS) Ciliwung dan Cisadane: Kajian Hilangnya Keanekaragaman Hayati. Laporan Akhir Program Insentif Peneliti dan Perekayasa LIPI Tahun 2010. Pusat Penelitian Biologi Lembaga Ilmu Pengetahuan Indonesia. Bogor. 